\title{
Young, gifted... and spurned
}

\author{
While their contemporaries in other countries zip \\ from postdoc to postdoc, young French scientists \\ struggle to find work. Sally Goodman reports.
}

\section{6}

'll just have to find any old job in a supermarket if I'm going to continue to feed my children," says geneticist Claire Amadou. For the past 18 months, Amadou has been working for free in a lab in Toulouse run by the CNRS, France's national research agency, living off her husband's salary. Having just discovered that the latest in a long line of applications for funding has failed, she is now is at the end of her tether. "All the other labs I've contacted have their own postdocs in the same situation. It's hopeless."

Amadou's plight is all too common in France. Scientists in universities and government labs are classed as civil servants - a protected breed who cannot be employed on temporary contracts. Limited numbers of postdoc contracts are funded by research charities and industry. But with no official postdoc system, the 7,000 $\mathrm{PhD}$ scientists the country churns out each year have few options. A lucky few land a coveted permanent job in the public research system; others find places in industry. But many more are left scrabbling around for scraps of funding, or find themselves out of work.

The government recognizes that there is a problem. Given that $40 \%$ of research staff in public labs and universities will retire over the next 10 years, officials realize that they cannot afford to let a generation of talent go to waste. To prevent their loss, science minister Roger-Gérard Schwartzenberg plans to create 800 new permanent posts in the public research agencies between now and 2010. At a press conference in Paris on 24 October, he talked of "an historic occasion to rejuvenate French research".

Schwartzenberg's plan — together with a

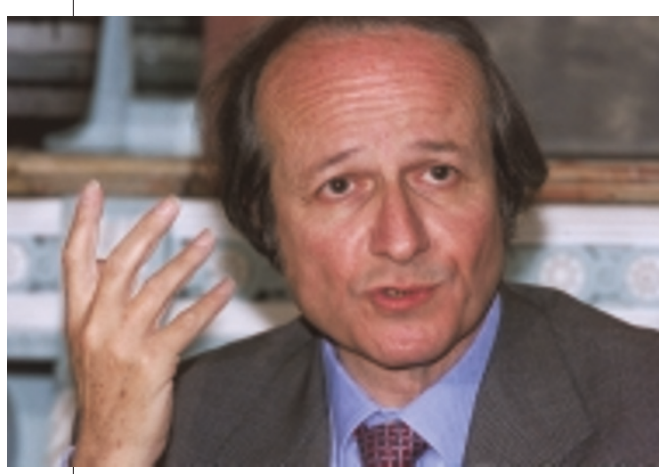

Roger-Gérard Schwartzenberg's plan to create new permanent posts misses the point, say critics.

NATURE |VOL 414 |8 NOVEMBER 2001| www.nature.com parallel effort announced in November 2000 to open 2,600 positions in the universities, a majority of which are likely to be in scientific disciplines - will provide a lifeline for many young French scientists. But critics argue that it leaves the underlying problems untouched. In essence, it is trying to fix the sclerosis caused by a system that has no stepping stone between $\mathrm{PhD}$ and a permanent job by creating yet more permanent positions.

The effective ban on universities and government research agencies employing French postdocs on short-term contracts creates some bizarre situations: advertisements for such positions often state that only foreign nationals will be considered. The fact that researchers must be given tenured posts from the beginning breeds conservatism and a lack of mobility between labs - hardly conducive to creating a vibrant research base. "Laboratories often prefer to recruit someone they know," says Rémi Barré, executive director of the public-interest group OST, which monitors trends in science and technology. "Anyone that moves off the defined path has a lot of problems finding a place." Amadou, for instance, spent three-and-a-half years working on a postdoc in Dallas, Texas.

Indeed, laboratories often design job descriptions to fit their own local candidates, and information on posts coming up is scarce. The recruitment process involves a laborious system of annual competitions, which is not well adapted to the needs of fastchanging research organizations. "The restrictions in place are extremely prohibitive" says Geneviève Berger, director general of the CNRS, "which is incomprehensible considering the number of potential recruits available and the budgets available to laboratories to fund them."

Some agencies are creating their own de facto postdoc programmes - although they are careful to describe payments as grants, not salaries, to avoid openly defying the rules. The medical research agency INSERM will in 2002 award 25 postdoc grants under an élite programme called Avenir - meaning 'future.' Researchers who are taken on will be given lab space and a working budget over three years with, at the end, the possibility of a permanent post. They will also be paid FFr15,000 (US\$2,000) a month about $50 \%$ more than most junior

\section{Bizarre situations}

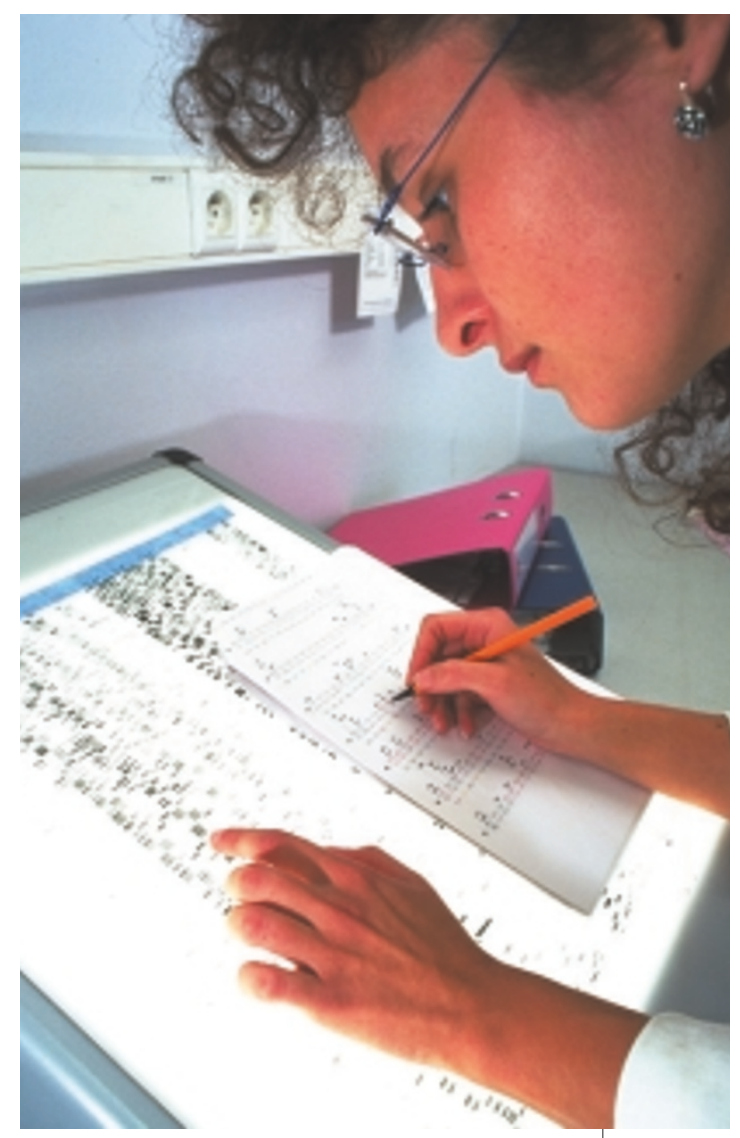

Gainfully employed: but many young French scientists find it impossible to get a suitable job.

researchers. Similar moves are afoot in leading independent medical research centres. The Pasteur Institute in Paris has instituted a scheme that will employ researchers on a five-year trial basis, following a mode already practised at the Curie Institute, also in Paris.

\section{French resistance}

But across most of the public and academic research system, inflexibility remains the norm. "Recruiting someone for life at 35 means that you may realize after five years that you have a super technician, but someone without the intellectual capacity to create their own research environment," says Daniel Louvard, director of research at the Curie Institute.

Solving that problem will require a brave science minister. Creating a genuine postdoc system would mean negotiating an exception from the rules governing the employment of civil servants. This system is protected by powerful vested interests, which will fight any exceptions tooth and nail. Science trade unions also oppose the introduction of postdoc contracts.

In the meantime, Schwartzenberg's plan is the best that is on offer. But many young scientists fear it will not be enough. As Amadou puts it: "Why would anyone want to be a researcher in France?"

Sally Goodman is Nature's French correspondent. 